\title{
DEVELOPING PANCOH ECOTOURISM-ORIENTED THEMATIC STRIP COMICS FOR ELEMENTARY SCHOOL STUDENTS
}

\author{
Shanta Rezkita, Latifatun Mukaromah \\ Universitas Sarjanawiyata Tamansiswa \\ shanta.rezkita@ustjogja.ac.id
}

\section{Article History}

accepted 30/09/2018

approved 12/10/2018

published 30/10/2018

\section{Keywords}

ecotourism, comic

strip, thematic,

elementary school.

\begin{abstract}
Education in the era of disruption must maintain the value of the nation's character. Ecotourism Pancoh has the potential as an educational space for environmental character. The packaging in comics is useful for civilizing literacy. This study aimed to describe the way of developing and knowing the quality and feasibility of ecotourism-oriented thematic strip comics. This study was research and development by adapting the model of Borg \& Gall. The data were collected by observation, unstructured interviews, and questionnaires. The comic trials were conducted for fifth grade students of Bhayangkara Elementary School, Yogyakarta. The data were analyzed by using qualitative and quantitative techniques. The assessment score of the media expert validation was 92,11 (very good), material expert was 95,33 (very good), teacher was 95,50 (very good), and student responses were 100 (very good). Thus the Pancoh ecotourism-oriented thematic strip comic was very feasible as a learning resource for elementary school students.
\end{abstract}

Social, Humanities, and Education Studies (SHEs): Conference Series https://jurnal.uns.ac.id/shes
p-ISSN 2620-9284

e-ISSN 2620-9292 


\section{PENDAHULUAN}

Peran dunia pendidikan saat ini sangat diharapkan untuk membentuk siswa yang berkarakter dan berbudaya. Manusia Indonesia berkarakter terpuji, tentu akan berpengaruh positif dalam menjaga keseimbangan lingkungan. Permasalahan lingkungan yang semakin kompleks dan pertambahan penduduk yang semakin meningkat membuat keseimbangan ekosistem menjadi terganggu. Oleh karena itu peranan sekolah penting untuk menjadi penggerak bagi keselamatan dunia demi hidup yang berkelanjutan. Proses ini tentunya dapat dimulai dari jenjang sekolah dasar.

Sekolah dasar adiwiyata Yogyakarta melaksanakan kurikulum yang ditetapkan oleh Kementerian Pendidikan dan Kebudayaan serta standar dari Kementerian Lingkungan Hidup dan Kehutanan. Proses PLH (Pendidikan Lingkungan Hidup) di sekolah dasar yang dilakukan secara berkelanjutan akan membentuk ekoliterasi (melek lingkungan). Namun demikian, Desfandi (2015) mengungkapkan pelaksanaan program sekolah adiwiyata berbasis PLH belum memberikan hasil yang maksimal untuk mencapai pembangunan berkelanjutan. Karena kerusakan lingkungan yang terjadi saat ini semakin parah.

Kebijakan pemerintah mencanangkan sekolah adiwiyata diharapkan dapat meningkatkan literasi masyarakat terhadap lingkungan. Literasi siswa sekolah dasar (SD) mengarah pada pemahaman siswa tentang hubungan dalam sistem kehidupan seperti sistem alam, sosial, teknologi dan lingkungan. Menurut Dian Aswita (2017) menyatakan bahwa ekowisata dapat menjadi sumber belajar bagi setiap orang. Hal ini dikarenakan dasar pengembangan sebuah ekowisata adalah pendidikan lingkungan. Oleh karena itu, ekowisata dan pendidikan lingkungan dapat saling mendukung. Namun demikian berdasakan hasil wawancara dengan beberapa guru pengembangan media dan sumber belajar di SD perlu ditingkatkan. Hal ini disebabkan oleh sebagian besar guru belum mengembangkan media pembelajaran yang sesuai dengan kebutuhan siswa, potensi daerah, dan potensi sekolah masing-masing. Guru-guru telah menggunakan media dalam pembelajaran namun belum maksimal dalam menumbuhkan kepedulian lingkungan siswa. Di sisi lain, guru juga masih kesulitan menerapkan pembelajaran tematik terpadu sesuai dengan yang diamanatkan kurikulum 2013. Sementara itu kesadaran siswa untuk menjaga lingkungan masih didikte oleh kepala sekolah dan guru. Misalnya pada pembuangan jenis sampah yang belum sesuai dengan tempatnya, sampah organik dan anorganik masih bercampur jadi satu.

Indonesia kaya akan potensi wisata, jika guru mampu berinovasi maka dengan mudah integrasi pembelajaran dilakukan di kelas. Kajian penelitian oleh Sutrisno \& Afendi (2018) mengindikasi konsep edu-ekowisata dapat diterapkan di Kawasan Gronggong dan berpotensi menjadi wisata Cirebon. Konsep yang dikembangkan adalah integrasi upaya konservasi lingkungan dengan desain ruang edukasi bertema lingkungan. Hasilnya setiap siswa di berbagai daerah dapat mengenal lingkungan alam, budaya, sosial, dan masyarakat Indonesia.

Apabila dilihat dari taraf berpikir siswa SD yang operasional konkret, sebaiknya pembelajaran dilaksanakan secara terpadu dengan menggunakan tema tertentu. Dengan demikian, siswa menjadi lebih fokus, dan memahami materi lebih mendalam. Selain itu lebih kontekstual karena mengaitkan pengalaman pribadi siswa. Agar siswa mampu membuat hubungan yang bermakna, dan meningkatkan penguasaan konsep siswa dapat melalui pembelajaran tematik (Direktorat Jenderal Guru dan Tenaga Kependidikan, 2016).

Pembelajaran tematik dapat menggunakan tema lingkungan. Hal ini diharapkan dapat memperkenalkan dan memperbahaui pemahaman siswa akan pentingnya kesadaran ekologis global. Tema ekoliterasi yang menggunakan potensi daerah dapat mengambil keunggulan desa Ekowisata Pancoh. Pancoh merupakan nama sebuah lokasi ekowisata terletak di desa Girikerto, Kecamatan Turi, Kabupaten Sleman Daerah 
Istimewa Yogyakarta. Ekowisata ini diberdayakan Lembaga Swadaya Masyarakat (LSM) setelah pasca erupsi Merapi. Beberapa potensi alam yang dimiliki seperti perkebunan salak, sayuran, peternakan, dan berbagai kerajinan, serta pelestarian budaya. Pada tanggal 12 Februari 2012, desa ekowisata ini diresmikan dengan SK 17/KPTS.KD/GK/IX/2015. Prestasi yang pernah diraih oleh ekowisata Pancoh seperti mendapat juara 1 se Kabupaten Sleman pada tahun 2016 kemudian juara 3 desa ekowisata se DIY, dari 144 desa wisata pada tahun 2017. Oleh karena itu pancoh ecotourism pada 31 Oktober 2017 s/d 1 Nopember 2017 berkesempatan mengikuti pameran di ajang International Conference On Sustainable Tourism, di Royal Ambarrukmo Hotel, Yogyakarta. Beberapa tujuan yang menarik dari ekowisata pancoh diantaranya memperkenalkan kekayaan ekologi Dusun Pancoh dan sekitarnya, menggerakkan perputaran roda perekonomian masyarakat khususnya Dusun Pancoh dan sekitarnya, menjaga, merawat dan mengembangkan SDA untuk tujuan yang baik dan benar, meningkatkan kualitas SDM dan kesejahteraan masyarakat, menciptakan kebersamaan, kerukunan dan gotong royong dengan sesama, dan terbangunnya sikap budaya peduli terhadap lingkungan (profil Pancoh Ekowisata, 2017).

Pemanfaatan potensi yang ada di ekowisata pancoh dalam pembelajaran di SD dapat memberikan gambaran yang kontekstual melalui melek lingkungan (ekoliterasi). (Boehnert, 2015) menjelaskan "Ecological literacy is a philosophical and educational programme that recognises human kind's essential relationship with the Earth and revisions educational, social, political and economic priorities for the design of sustainable ways of living". Ekoliterasi sangat diperlukan dalam program pendidikan yang menggambarkan bahwa antara kehidupan manusia dan bumi memiliki hubungan yang kuat. Bahkan di bidang politik, sosial dan ekonomi dalam mendesain gaya hidup yang berkelanjutan. Asas dalam ekoliterasi dapat ditumbuhkan melalui pendidikan sekolah dan luar sekolah, dari taman kanak-kanak hingga perguruan tinggi. Dengan demikian, setiap orang muncul kesadarannya untuk melestarikan lingkungan.

Salah satu cara untuk membantu siswa dalam memahami materi pembelajaran dapat menggunakan media yang tepat dan bervariasi seperti komik strip dalam pembelajaran tematik. Cerita yang disajikan dalam bentuk gambar yang berurutan akan memberi pesan moral dan mengembangkan imajinasi anak-anak. Namun seiring perkembangannya, menurut Soedarso (2015) komik lokal seolah tidak mampu bersaing dengan komik luar negeri. Oleh karena itu, perlu dilakukan upaya melestarikan keberadaan komik lokal di Indonesia, misalnya dengan mengaitkan antara cerita komik dengan fenomena lingkungan.

Upaya melek lingkungan dapat dimediasi melalui komik sehingga menciptakan pembelajaran yang menarik bagi siswa SD. Komik dalam Kamus Besar Bahasa Indonesia oleh Pusat Bahasa (2008) diartikan sebagai cerita bergambar dan pelawak atau badut. Lebih lanjut McCloud (2008) memaparkan bahwa komik adalah sebuah media yang berupa kepingan-kepingan teks dan potongan gambar yang ketika bergabung akan menjadi cerita yang utuh dan berkesinambungan. Oleh karena itu, komik terkesan hidup ketika dibaca. Tidak heran jika komik dapat membangkitkan minat, mengembangkan perbendaharaan kata-kata dan keterampilan membaca serta meningkatkan minat baca siswa. Komik dalam pembelajaran akan mengubah pandangan negatif masyarakat selama ini sehingga menjadi bacaan yang bermanfaat bagi pembelajaran (Sudjana, 2009).

Sementara itu berdasarkan jenisnya, komik dibagi menjadi dua, yaitu komik buku dan komik strip. Sobur (2009) menyatakan komik strip hanya terdiri dari beberapa panel gambar, namun dari segi isinya telah mengungkapkan sebuah gagasan yang utuh. Hal ini dikarenakan tampilannya yang sedikit gambar dan gagasan namun telah memuat berbagai peristiwa dan isu-isu mutakhir. Biasanya komik ini dimuat pada surat kabar dan majalah anak, misalnya majalah bobo dan kids fantasi. Perbedaan kedua jenis komik tersebut terlihat dari bentuk penampilan atau kemasan. Komik juga dapat 
dimanfaatkan dalam dunia pendidikan sebagai media pembelajaran, bahkan mampu menyesuaikan dengan tujuan tertentu. Oleh karena itu perlu dikembangkan komik strip berorientasi ekowisata pancoh sebagai media pembelajaran berbentuk cerita bergambar sederhana dengan tema tertentu dan memuat sejumlah konsep dari berbagai mata pelajaran yang terkait dengan potensi lingkungan dusun Pancoh sehingga menambah pengetahuan lingkungan siswa.

\section{METODE}

Berdasarkan tujuan yang dicapai, penelitian ini menggunakan metode Research and Development (R\&D) atau penelitian dan pengembangan. Model pengembangan diadaptasi dari rancangan Borg \& Gall (1983) dengan tahapan, 1) penelitian dan pengumpulan informasi; 2) perencanaan; 3) pengembangan produk; 4) uji coba awal; 5) revisi produk; 6) uji coba lapangan; dan 7) revisi produk uji lapangan. Ketujuh tahapan ini kemudian dimodifikasi menjadi tiga tahapan yaitu studi pendahuluan, desain produk, pengembangan produk dan evaluasi.

Teknik pengumpulan data dilakukan melalui observasi, wawancara tidak terstruktur, dan angket. Instrumen ini diuji dengan menggunakan validitas isi. Instrumen menggunakan cek (check list) tentang kualitas komik strip. Kualitas dari komik ini dinilai dari beberapa aspek yaitu kelayakan isi materi, kebenaran konsep, kedalaman, konsep, keluasan konsep, keterlaksanaan, kebahasaan, anatomi komik, dan tampilan menyeluruh. Instrumen penilaian komik juga diberikan penjabaran (kisikisi) dari kriteria penilaian untuk dimasukkan ke dalam kategori nilai yang sesuai. Instrumen ini kemudian diuji validitasnya ahli media dan materi.

Skor dari setiap validator merupakan data kuantitatif yang selanjutnya dikonversi menjadi data kualitatif sesuai kriteria kategori penilaian kualitas ideal dengan ketentuan sebagai berikut.

Tabel 1. Kriteria kategori penilaian kualitas ideal

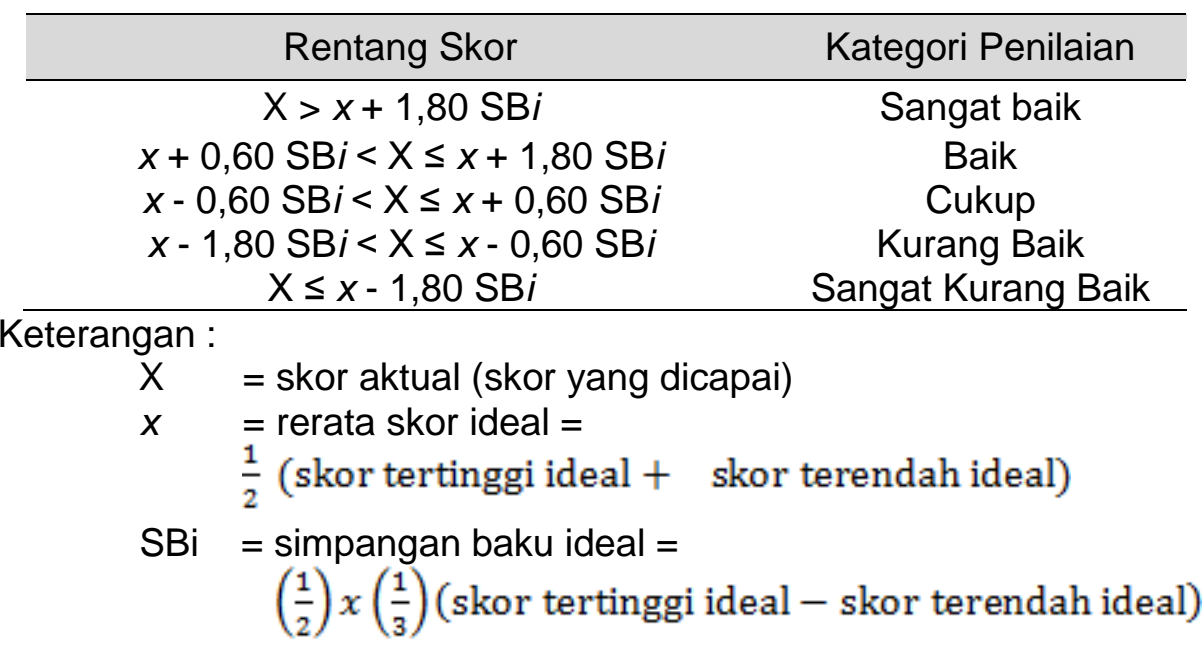

Skor tertinggi ideal $=\sum$ butir kriteria $\mathrm{x}$ skor tertinggi

Skor terendah ideal $=\sum$ butir kriteria $\mathrm{x}$ skor terendah 
HASIL DAN PEMBAHASAN

Hasil validasi produk komik strip tematik oleh ahli materi diperoleh data seperti Gambar 1 berikut.

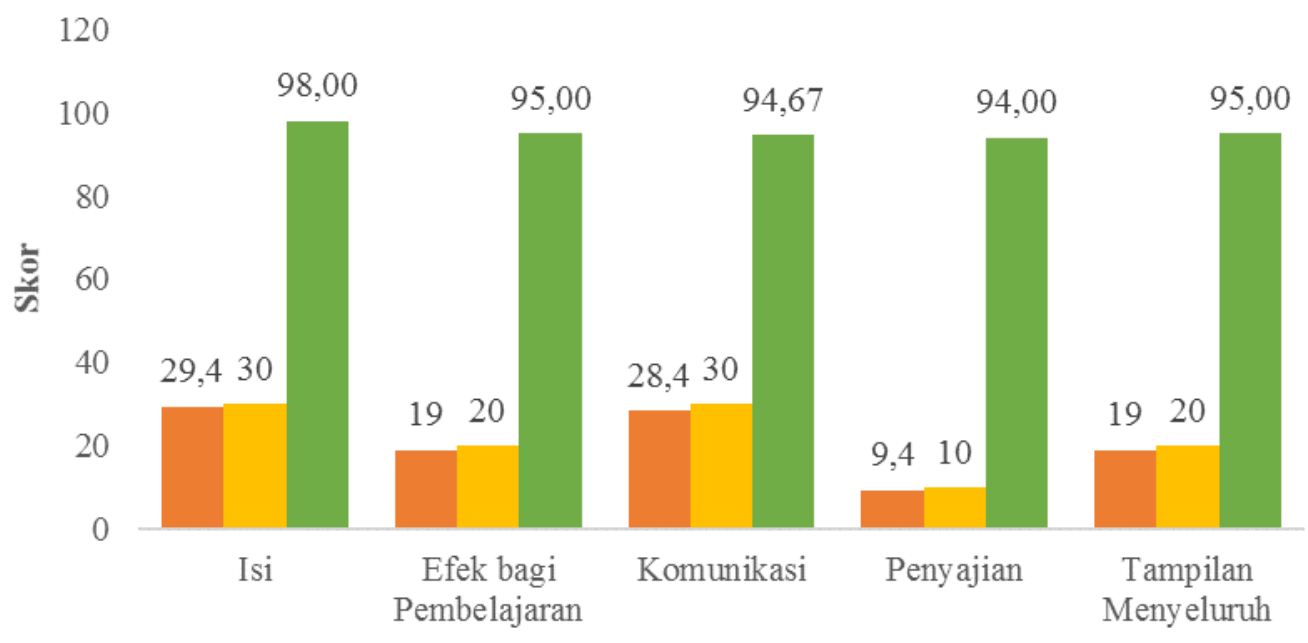

Aspek Penilaian

घ Skor Perolehan $\square$ Skor Maksimal Ideal $\quad$ Persentase Keidealan

\section{Gambar 1. Penilaian Ahli Materi terhadap Kualitas Komik Strip Tematik}

Gambar 1 menunjukkan persentase keidealan tertinggi komik strip tematik terdapat pada aspek isi, sedangkan perolehan skor rata-rata seluruh aspek adalah 105,2 dengan persentase keidealan $95,33 \%$ dan kriteria kategori ideal seperti pada Tabel 2.

Tabel 2. Kriteria Kualitas Komik Strip Tematik Berdasarkan Penilaian Ahli Materi

\begin{tabular}{|c|c|c|}
\hline No & Rentang Skor & Kategori \\
\hline 1 & $\mathrm{X}>92,4$ & Sangat baik \\
\hline 2 & $74,8<\mathrm{X} \leq 92,4$ & Baik \\
\hline 3 & $57,2<\mathrm{X} \leq 74,8$ & Cukup \\
\hline 4 & $39,6<\mathrm{X} \leq 57,2$ & Kurang Baik \\
\hline 5 & $\mathrm{X} \leq 39,6$ & Sangat Kurang Baik \\
\hline
\end{tabular}

Skor ini terletak pada interval $X>92,4$ sehingga komik strip tematik dari segi materi berada pada kategori Sangat Baik (SB). Gambar 2. 


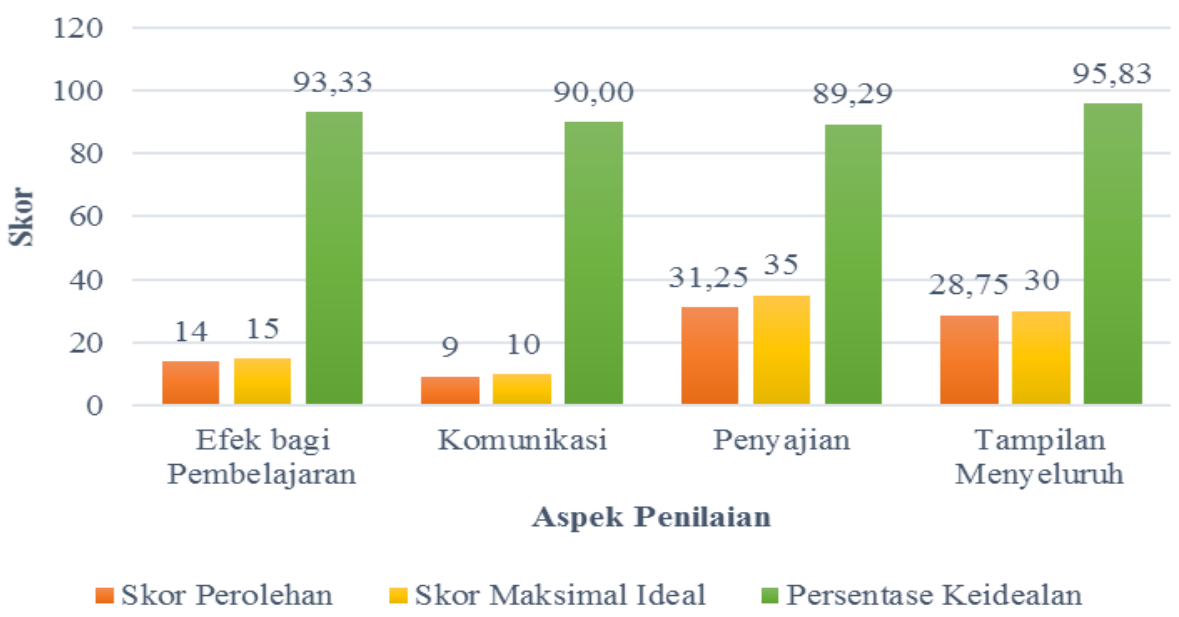

\section{Gambar 2. Penilaian Ahli Media terhadap Kualitas Komik Strip Tematik}

Gambar 2 menunjukkan persentase keidealan tertinggi komik strip tematik terdapat pada aspek tampilan secara menyeluruh, sedangkan perolehan skor rata-rata seluruh aspek adalah 83 dengan persentase keidealan 92,11\% dan kriteria kategori ideal seperti Tabel 3.

Tabel 3. Kriteria Kualitas Komik Strip Tematik Berdasarkan Penilaian Ahli Media

\begin{tabular}{cc}
\hline Rentang Skor & Kategori \\
\hline$X>75,6$ & Sangat baik \\
$61,2<X \leq 75,6$ & Baik \\
$46,8<X \leq 61,2$ & Cukup \\
$32,4<X \leq 46,8$ & Kurang Baik \\
$X \leq 32,4$ & Sangat Kurang Baik \\
\hline
\end{tabular}

Skor ini terletak pada interval $X>75,6$ sehingga komik strip tematik dari segi media berada pada kategori Sangat Baik (SB).

Hasil validasi produk komik strip tematik oleh guru tersaji seperti Gambar 3 berikut.

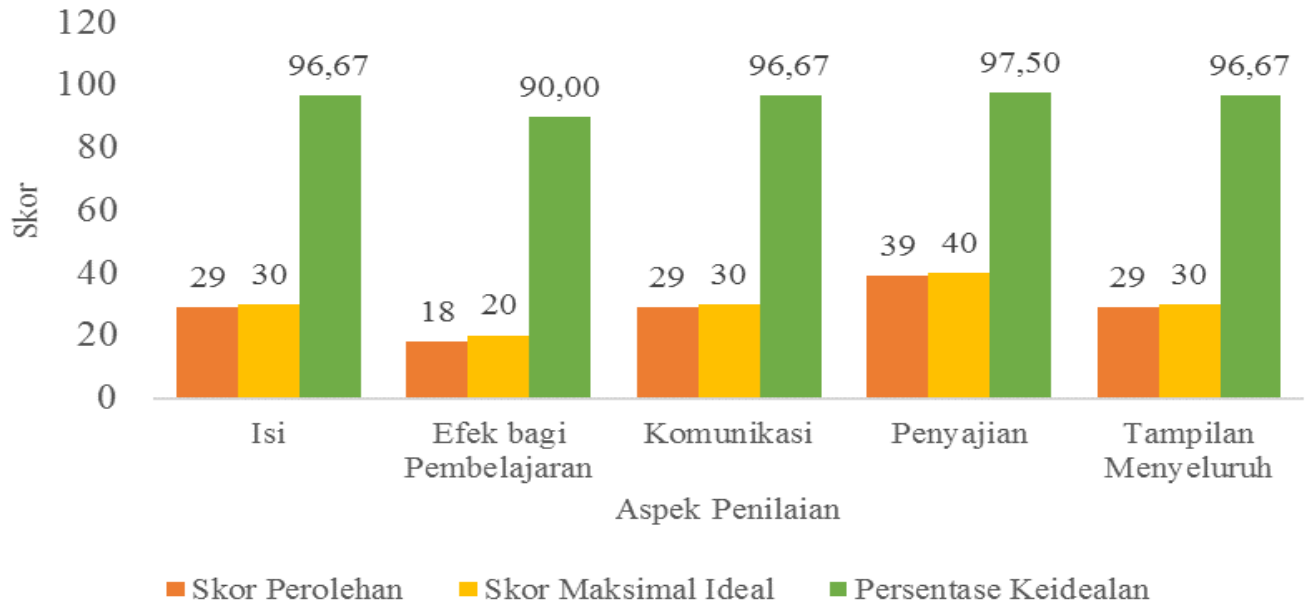

Gambar 3. Penilaian Guru terhadap Kualitas Komik Strip Tematik 
Gambar 3 menunjukkan persentase keidealan tertinggi komik strip tematik terdapat pada aspek penyajian, sedangkan perolehan skor rata-rata seluruh aspek adalah 144 dengan persentase keidealan 95,50\% dan kriteria kategori ideal seperti Tabel 4.

Tabel 4. Kriteria Kualitas Komik Strip Tematik Berdasarkan Penilaian Guru

\begin{tabular}{cc}
\hline Rentang Skor & Kategori \\
\hline$X>126$ & Sangat baik \\
$102<X \leq 126$ & Baik \\
$78<X \leq 102$ & Cukup \\
$54<X \leq 78$ & Kurang Baik \\
$X \leq 54$ & Sangat Kurang Baik \\
\hline
\end{tabular}

Skor ini terletak pada interval $X>126$ sehingga komik strip tematik berada pada kategori Sangat Baik (SB).

Hasil respon siswa terhadap komik strip tematik dapat dilihat pada Gambar 4.

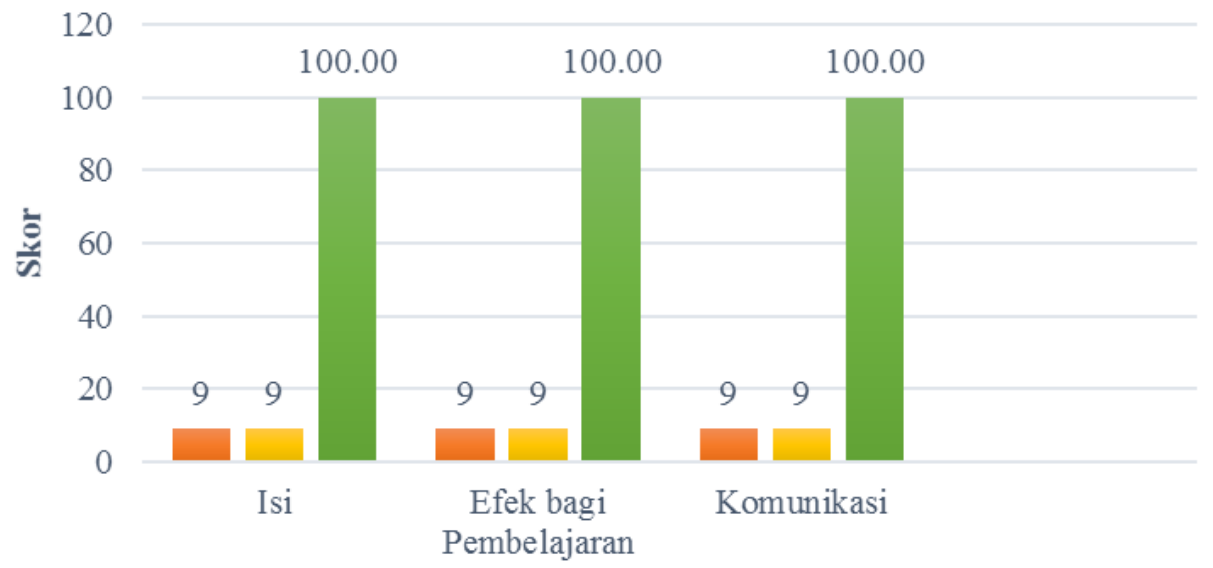

Aspek Penilaian

- Skor Perolehan $\square$ Skor Maksimal Ideal $\quad$ Persentase Keidealan

\section{Gambar 4. Respon Siswa terhadap Komik Strip Tematik}

Gambar 4. menunjukkan skor rata-rata seluruh aspek adalah 27 dengan persentase keidealan $100 \%$. Artinya semua siswa merespon sangat baik terhadap komik strip tematik.

Ekowisata Pancoh memiliki potensi yang dapat dijadikan sebagai sumber belajar bagi siswa sekolah dasar. Berbagai potensi diantaranya wisata alam, edukasi, budaya, dan sejarah. Potensi wisata alam Pancoh meliputi pemandangan alam dengan latar Gunung Merapi, waduk, kolam ikan, sungai, sawah kebun salak, kebun bunga. Potensi wisata edukasi Pancoh meliputi pembuatan kerajinan tangan (caping art, membatik, handmade dari barang bekas), pembelajaran seni budaya, penanaman, perawatan serta pemetikan buah salak, Penanaman, perawatan serta pemetikan bunga, pembuatan biogas, pembajakan sawah, dan penangkapan ikan. Potensi wisata budaya Pancoh meliputi nyadran, karawitan, laras madyo, bungbeh (dolanan anak). Potensi wisata outbond Pancoh meliputi susur sungai dan fun game. Potensi wisata sejarah Pancoh yaitu keberadaan Gedung "Londo" sebagai bangunan bersejarah peninggalan 
Belanda. Oleh karena itu, ekowisata Pancoh berbeda dengan wisata konvensional lainnya karena mengarah pada lingkungan alam, sosial, dan budaya.

Berdasarkan potensi ekowisata Pancoh kemudian dilakukan pembuatan komik strip tematik dengan adaptasi model pengembangan Borg and Gall, yaitu penelitian dan pengumpulan informasi, perencanaan, pengembangan produk, uji coba awal revisi produk, uji coba lapangan, dan revisi produk uji lapangan. Produk akhir dari pengembangan adalah komik strip tema lingkungan sahabat kita untuk siswa kelas $\mathrm{V}$ sekolah dasar melalui dua kali kali revisi. Revisi pertama berdasarkan masukan dari ahli materi dan ahli media mencakup tata tulis, balon percakapan, penjelasan istilahistilah pada percakapan, tambahan keterangan sungai, awan, tanah dan infiltrasi pada gambar siklus air, membuat jeda pengantar cerita (dibagi dalam strip-strip), membuat gambar lebih proporsional, pemberian warna cover lebih menarik. Revisi kedua berdasarkan masukan dari guru dan siswa mencakup keterangan tambahan kelas $\mathrm{V}$ pada judul cover dan ilustrasi cerita yang mengarah pada karakter peduli lingkungan.

Pengetahuan lingkungan dibutuhkan semua masyarakat. Ketika sejak usia sekolah dasar sudah memiliki pengetahuan lingkungan yang baik dan dilatih kepekaannya terhadap lingkungan maka diharapkan dewasanya dapat ikut menjaga dan melestarikan lingkungan. Namun hubungan antara pengetahuan, kepekaan, dengan perilaku lingkungan kadang tidak sejalan. Hal ini dikarenakan perilaku seseorang terhadap lingkungan berkaitan erat dengan budaya dan lingkungan keluarga, sehingga butuh waktu untuk mengubah perilaku tersebut. Literasi lingkungan (ekoliterasi) memuat tiga dimensi yang saling berhubungan, yaitu integrasi sikap dan kepekaan lingkungan, perilaku pro lingkungan dan pengetahuan lingkungan. Siswa yang lebih berpengetahuan tentang lingkungan memiliki kepekaan dan sikap yang kuat tetapi tidak selalu memiliki perilaku pro-lingkungan yang kuat. Oleh karena itu butuh upaya agar tercapai pengetahuan, kepekaan lingkungan, dan perilaku pro lingkungan yang lebih tinggi (Nunez \& Clores, 2017).

Hasil analisis data dapat dimaknai bahwa komik strip tematik berorientasi ekowisata Pancoh sangat baik dijadikan media karena sarat akan pendidikan karakter dan isi ceritanya sesuai dengan kompetensi dasar dan tujuan pembelajaran. Hal ini diperkuat Richter, Rendigs, \& Maminirina (2015) bahwa kolaborasi penggunaan komik dengan materi tambahan tentang kondisi lokal suatu daerah dapat meningkatkan pengetahuan lingkungan siswa sekolah dasar. Kemasan komik dengan beberapa episode tematik memberikan pembelajaran inovatif dan bermakna bagi siswa sehingga mereka mengenal potensi lokal dalam pendidikan lingkungan. Pengetahuan lingkungan yang diperoleh menjadi prasyarat siswa untuk mengembangkan sikap positif yang kemudian mendorong perilaku atau karakter peduli lingkungan.

\section{SIMPULAN}

Berdasarkan hasil yang telah dicapai dapat disimpulkan bahwa (1) Komik strip tematik berorientasi ekowisata Pancoh berpotensi untuk dikembangkan sesuai dengan tujuan sekolah dasar adiwiyata. (2) Prosedur pengembangan komik strip tematik berorientasi ekowisata Pancoh dilakukan dengan adaptasi model pengembangan Borg and Gall, yaitu penelitian dan pengumpulan informasi, perencanaan, pengembangan produk, uji coba awal revisi produk, uji coba lapangan, dan revisi produk uji lapangan. (3) Komik strip tematik berorientasi ekowisata Pancoh sangat baik dijadikan media karena sarat akan pendidikan karakter dan isi ceritanya sesuai dengan kompetensi dasar dan tujuan pembelajaran kelas $\mathrm{V}$ sekolah dasar. Namun disarankan pada penelitian selanjutnya dapat mengembangkan komik strip digital dan diujicoba luas terkait efektivitas penggunaannya dalam pembelajaran tematik di sekolah dasar adiwiyata. 


\section{DAFTAR PUSTAKA}

Boehnert, J. (2015). Ecological Literacy in Design Education: A Theoretical Introduction. Form Akademisk - Research Journal of Design and Design Education, 8(1), 1-11.

Borg, Walter R \& Gall, Meredith D. (1983). Educational Research an Introduction, Fourth Edition. New York: Longman Inc.

Dian Aswita. (2018). Environmental Education and Ecotourism for Sustainable Life: Literature Study. Jurnal IImiah Peuradeun The International Journal of Social Sciences Vol. 6, No. 1, January 2018. Page. 17-30. doi: 10.26811/peuradeun.v6i1.157

Direktorat Jenderal Guru dan Tenaga Kependidikan. (2016). Guru Pembelajar: Modul Pelatihan SD Kelas Awal: Pedagogik Pengembangan dan Pelaksanaan Kurikulum di Sekolah Dasar. Jakarta: Kemendikbud.

Desfandi, M. (2015). Mewujudkan Masyarakat Berkarakter Peduli Lingkungan Melalui Program Adiwiyata. SOSIO DIDAKTIKA: Social Science Education Journal, 2(1), 2015, 31-37. doi:10.15408/ sd.v2i1.1661

Pusat Bahasa. (2008). Kamus Besar Bahasa Indonesia. Edisi keempat. Jakarta: Gramedia Pustaka Umum.

McCloud, Scott. (2008). Mencipta Ulang Komik (Reinventing Comics). Edisi Revisi. Jakarta: KPG (Kepustakaan Populer Gramedia).

Nunez, M. B., \& Clores, M. A. (2017). Environmental Literacy of K - 10 Student Completers, 12(5), 1195-1215.

Richter, T., Rendigs, A., \& Maminirina, C. P. (2015). Conservation Messages in Speech Bubbles-Evaluation of an Environmental Education Comic Distributed in Elementary Schools in Madagascar, 8855-8880. https://doi.org/10.3390/su7078855

Sobur, Alex. (2009). Analisis Teks Media. Bandung: Remaja Rosdakarya.

Soedarso, Nick. (2015). Komik: Karya Sastra Bergambar. Humaniora, Vol. 6 No. 4 Oktober 2015, 496-506.

Sudjana, Rivai. (2009). Media pengajaran. Edisi Revisi. Bandung: Penerbit Sinar Baru Algensindo.

Sutrisno, A. N., \& Afendi, A. H. (2018). Penerapan Konsep Edu-Ekowisata sebagai Media Pendidikan Karakter Berbasis Lingkungan, 1-11. 